Correspondence Svetlana N. Dedysh dedysh@mail.ru

\section{Methyloferula stellata gen. nov., sp. nov., an acidophilic, obligately methanotrophic bacterium that possesses only a soluble methane monooxygenase}

\author{
Alexey V. Vorobev, ${ }^{1}$ Mohamed Baani, ${ }^{2}$ Nina V. Doronina, ${ }^{3}$ Allyson L. Brady, ${ }^{4}$ \\ Werner Liesack, ${ }^{2}$ Peter F. Dunfield ${ }^{2,4}$ and Svetlana N. Dedysh ${ }^{1}$ \\ ${ }^{1}$ S. N. Winogradsky Institute of Microbiology, Russian Academy of Sciences, Moscow 117312, Russia \\ ${ }^{2}$ Max-Planck-Institut für terrestrische Mikrobiologie, D-35043 Marburg, Germany \\ ${ }^{3}$ G. K. Skryabin Institute of Biochemistry and Physiology of Microorganisms, Russian Academy of \\ Sciences, Pushchino, Moscow region 142292, Russia \\ ${ }^{4}$ Department of Biological Sciences, University of Calgary, Calgary, Alberta, Canada
}

Two strains of aerobic methanotrophic bacteria, $A R 4^{\top}$ and SOP9, were isolated from acidic (pH 3.8-4.0) Sphagnum peat bogs in Russia. Another phenotypically similar isolate, strain LAY, was obtained from an acidic ( $\mathrm{pH} 4.0)$ forest soil in Germany. Cells of these strains were Gramnegative, non-pigmented, non-motile, thin rods that multiplied by irregular cell division and formed rosettes or amorphous cell conglomerates. Similar to Methylocella species, strains AR4 ${ }^{\top}$, SOP9 and LAY possessed only a soluble form of methane monooxygenase (sMMO) and lacked intracytoplasmic membranes. Growth occurred only on methane and methanol; the latter was the preferred growth substrate. mRNA transcripts of sMMO were detectable in cells when either methane or both methane and methanol were available. Carbon was assimilated via the serine and ribulose-bisphosphate (RuBP) pathways; nitrogen was fixed via an oxygen-sensitive nitrogenase. Strains AR4 ${ }^{\top}$, SOP9 and LAY were moderately acidophilic, mesophilic organisms capable of growth between $\mathrm{pH} 3.5$ and 7.2 (optimum $\mathrm{pH} 4.8-5.2$ ) and at $4-33^{\circ} \mathrm{C}$ (optimum $20-23{ }^{\circ} \mathrm{C}$ ). The major cellular fatty acid was $18: 1 \omega 7 \mathrm{c}$ and the quinone was $\mathrm{Q}-10$. The DNA $\mathrm{G}+\mathrm{C}$ content was $55.6-57.5 \mathrm{~mol} \%$. The isolates belonged to the family Beijerinckiaceae of the class Alphaproteobacteria and were most closely related to the sMMO-possessing methanotrophs of the genus Methylocella (96.4-97.0\% 16S rRNA gene sequence similarity), particulate MMO (pMMO)-possessing methanotrophs of the genus Methylocapsa (96.1-97.0\%), facultative methylotrophs of the genus Methylovirgula (96.1-96.3\%) and non-methanotrophic organotrophs of the genus Beijerinckia (96.5-97.0\%). Phenotypically, strains AR4 ${ }^{\top}$, SOP9 and LAY were most similar to Methylocella species, but differed from members of this genus by cell morphology, greater tolerance of low $\mathrm{pH}$, detectable activities of RuBP pathway enzymes and inability to grow on multicarbon compounds. Therefore, we propose a novel genus and species, Methyloferula stellata gen. nov., sp. nov., to accommodate strains AR4 ${ }^{\top}$, SOP9 and LAY. Strain AR4 ${ }^{\top}$ (=DSM $22108^{\top}=$ LMG $25277^{\top}=$ VKM B-2543 ${ }^{\top}$ ) is the type strain of Methyloferula stellata.
Aerobic methanotrophs are a unique group of methylotrophic bacteria that utilize methane as a sole carbon and energy source. At present, methanotrophic capabilities are recognized in members of two bacterial phyla, the Proteobacteria and Verrucomicrobia (Hanson \& Hanson, 1996; Op den Camp et al., 2009). Almost all known

Abbreviations: ICM, intracytoplasmic membrane; PLFA, phospholipid fatty acid; pMMO, particulate-form methane monooxygenase; RuBP, ribulose 1,5bisphosphate; RubisCO, ribulose-1,5-bisphosphate carboxylase/oxygenase; sMMO, soluble-form methane monooxygenase.

The GenBank/EMBL/DDBJ accession numbers for the 16S rRNA gene sequences and partial mmoX gene sequences of strains AR4 ${ }^{\top}$, SOP9 and LAY are FR686343-FR686345 (16S rRNA gene) and FR686346-FR686348 ( $m m \circ X)$, respectively, and those for the partial $m \times a F$, nifH and $r b c L$ sequences of strain $A R 4^{\top}$ are FR686349, FR686351 and FR686352, respectively.

Three supplementary figures are available with the online version of this paper. 
methanotrophs possess a particulate methane monooxygenase enzyme (pMMO) and contain a well-developed intracytoplasmic membrane (ICM) system in which pMMO is bound. The only known exceptions are representatives of the genus Methylocella, which possess only a soluble methane monooxygenase (sMMO) and lack an extensive ICM system (Dedysh et al., 2000, 2004a; Dunfield et al., 2003; Chen et al., 2010). Another unique characteristic of Methylocella species is the ability to utilize a number of multicarbon compounds (Dedysh et al., 2005a; Dedysh \& Dunfield, 2010). sMMO in Methylocella is repressed if an alternative, multicarbon growth substrate is present, but is not affected by copper ion availability (Theisen et al., 2005).

Members of the genus Methylocella are widely distributed in acidic to neutral terrestrial environments, especially in peatlands and acidic soils (Dedysh \& Dunfield, 2010). Due to the absence of pMMO in Methylocella species, these bacteria cannot be detected using a pmoA-based PCR assay considered universal and specific for all other known methanotrophs. However, they do possess the $m m o X$ gene, encoding the $\alpha$-subunit of sMMO, and can be detected via retrieval of these genes from the environment. Here, we describe three novel methanotrophs of a similar nature, strains $\mathrm{AR} 4^{\mathrm{T}}$, SOP9 and LAY, which also lack a pMMO and use only an sMMO for methane oxidation. It is remarkable that the mmoX gene could not be amplified from DNA of our novel isolates with any of the previously known mmoX-targeted primers (McDonald et al., 1995; Miguez et al., 1997; Shigematsu et al., 1999; Auman et al., 2000). This explains why these methanotrophs escaped detection in all former cultivation-independent studies. In our paper, we present detailed characterization of these novel, sMMOpossessing methanotrophs and propose a novel genus and species for these bacteria.

Strains $\mathrm{AR} 4^{\mathrm{T}}$ and SOP9 were respectively isolated from an acidic peat soil ( $\mathrm{pH} 3.8)$ sampled at a depth of $10 \mathrm{~cm}$ of the oligo-mesotrophic fen Torfjanoye, Archangelsk region, European North Russia $\left(65^{\circ} 01^{\prime} \mathrm{N} 35^{\circ} 44^{\prime} \mathrm{E}\right)$, and a peat soil ( $\mathrm{pH} 4.0$ ) sampled at a depth of $10-20 \mathrm{~cm}$ of the Sphagnum peat bog Bakchar, West Siberia, Russia ( $56^{\circ} 51^{\prime}$ $\mathrm{N} 82^{\circ} 51^{\prime}$ E). Two methanotrophic enrichment cultures were obtained from these peat samples using liquid mineral medium MM2 of the following composition (per litre demineralized water): $\mathrm{KH}_{2} \mathrm{PO}_{4}, 100 \mathrm{mg} ;\left(\mathrm{NH}_{4}\right)_{2} \mathrm{SO}_{4}$, $100 \mathrm{mg} ; \mathrm{MgSO}_{4} .7 \mathrm{H}_{2} \mathrm{O}, 50 \mathrm{mg} ; \mathrm{CaCl}_{2} .2 \mathrm{H}_{2} \mathrm{O}, 20 \mathrm{mg}$; $\mathrm{pH}$ 4.8-5.2. Isolation of methanotrophs from the resulting enrichment cultures was achieved by plating an aliquot of the respective cell suspensions on medium MM2 solidified with gellan gum (Gel-Gro; ICN Biomedicals). The third isolate, strain LAY, was obtained from an acidic $(\mathrm{pH} 4.0)$ forest soil near Marburg, Germany, by plating a soil suspension onto the surface of diluted nitrate mineral agar salts (DNMS) medium at $\mathrm{pH} 5.8$ as described by Dunfield et al. (2003). Inoculated plates were incubated for 1.5 months at $24{ }^{\circ} \mathrm{C}$ in a closed glass desiccator containing a headspace of $20 \%(\mathrm{v} / \mathrm{v})$ methane and $5 \% \mathrm{CO}_{2}(\mathrm{v} / \mathrm{v})$ in air.
Colonies that developed on these plates were picked and purified by successive restreaking.

The isolates were maintained on their respective solid media (medium MM2 for strains $\mathrm{AR} 4^{\mathrm{T}}$ and SOP9 and DNMS medium for strain LAY) and in liquid cultures. For growth in liquid media, $500 \mathrm{ml}$ screw-capped serum bottles were used with a headspace/liquid space ratio of $4: 1$. After inoculation, methanol was added aseptically to the cultures and the bottles were capped with silicone rubber septa to prevent loss of methanol by evaporation, or methane was added aseptically through silicone rubber septa to achieve a gas-mixing ratio in the headspace of approximately $10-20 \%$. Bottles were incubated on a rotary shaker (120 r.p.m.) at $24{ }^{\circ} \mathrm{C}$.

Morphological observations and cell-size measurements were made with a Zeiss Axioplan 2 microscope and Axiovision 4.2 software (Zeiss). For the preparation of ultrathin sections, cells from cultures grown in liquid medium MM2 under methane were collected by centrifugation and pre-fixed with $1.5 \%(\mathrm{w} / \mathrm{v})$ glutaraldehyde in $0.05 \mathrm{M}$ cacodylate buffer $(\mathrm{pH} 7.2)$ for $1 \mathrm{~h}$ at $4{ }^{\circ} \mathrm{C}$ and then fixed in $1 \%(\mathrm{w} / \mathrm{v}) \mathrm{OsO}_{4}$ in the same buffer for $4 \mathrm{~h}$ at $20{ }^{\circ} \mathrm{C}$. After dehydration in an ethanol series, the samples were embedded in an Epon 812 epoxy resin. Thin sections were cut on an LKB-2128 Ultrotome, stained with $3 \%(w / v)$ uranyl acetate in $70 \%(\mathrm{v} / \mathrm{v})$ ethanol and then post-stained with lead citrate (Reynolds, 1963) at $20{ }^{\circ} \mathrm{C}$ for $4-5 \mathrm{~min}$. Samples were examined with a JEM-100B transmission electron microscope at $80 \mathrm{kV}$ accelerating voltage.

Physiological tests were performed in liquid medium MM2 with $0.5 \%(\mathrm{v} / \mathrm{v})$ methanol as the sole growth substrate. Growth of isolates was monitored by nephelometry at $600 \mathrm{~nm}$ for 2 weeks under a variety of growth conditions, including temperatures of $4-37{ }^{\circ} \mathrm{C}, \mathrm{pH} 2.9-8.0$ and $\mathrm{NaCl}$ at concentrations of $0.01-5 \%(\mathrm{w} / \mathrm{v})$. Variations in $\mathrm{pH}$ were achieved by mixing $0.1 \mathrm{M}$ solutions of $\mathrm{H}_{2} \mathrm{SO}_{4}$ and $\mathrm{NaOH}$. The range of potential growth substrates was examined using $0.05 \%(\mathrm{w} / \mathrm{v})$ concentrations of the following carbon sources: formamide, formaldehyde, methylamine, dimethylamine, trimethylamine, glucose, arabinose, xylose, lactose, maltose, rhamnose, raffinose, sucrose, sorbose, fructose, formate, acetate, lactate, malate, oxalate, pyruvate, propionate, succinate, citrate, valerate, capronate, gluconate, glucuronate, mannitol, myo-inositol and ethanol. Nitrogen sources were tested by replacing $\left(\mathrm{NH}_{4}\right)_{2} \mathrm{SO}_{4}$ in $\mathrm{MM} 2$ with $0.01 \%(\mathrm{w} / \mathrm{v}) \mathrm{KNO}_{3}, \mathrm{NaNO}_{2}$, urea, glycine, alanine, serine, cysteine, proline, arginine, asparagine or yeast extract.

Cell biomass for cellular fatty acid and isoprenoid quinone analyses and for DNA extraction was obtained from batch cultures grown in liquid medium MM2 with methanol at $24{ }^{\circ} \mathrm{C}$ for 10 days. Fatty acid profiles were analysed at the Identification Service of the Deutsche Sammlung von Mikroorganismen und Zellkulturen (DSMZ, Braunschweig, Germany) as described by Kämpfer \& Kroppenstedt (1996). Isoprenoid quinones were extracted according to Collins (1985) and analysed using liquid 
chromatography coupled with tandem mass spectrometry (Finnigan LCQ Advantage Max and Mat 8430 system; Thermo Fisher Electronic).

The DNA base composition of strains was determined by thermal denaturation using a Unicam SP1800 spectrophotometer at a heating rate of $0.5{ }^{\circ} \mathrm{C} \mathrm{min}{ }^{-1}$. The DNA G $+\mathrm{C}$ content was calculated according to Owen et al. (1969). PCR-mediated amplification of the 16S rRNA gene was performed using primers $9 \mathrm{f}$ and $1492 \mathrm{r}$ and reaction conditions described by Weisburg et al. (1991). Partial fragments of the mxaF gene (encoding the large subunit of methanol dehydrogenase), the nifH gene (encoding dinitrogen reductase) and the $r b c L$ gene [encoding the large subunit of form I ribulose-1,5-bisphosphate (RuBP) carboxylase/oxygenase (RubisCO)] were amplified using primers and reaction conditions described, respectively, by McDonald \& Murrell (1997), Dedysh et al. (2004b) and Spiridonova et al. (2004). PCR-mediated amplification of the $m m o X$ gene was performed using a combination of the previously described forward primer mmoXA (166f) (Auman et al., 2000) and the newly developed reverse primer mmoXmcl (1353r) (5'-VCGYTCGCCCCARTCRTC- $3^{\prime}$ ), which was designed to target specifically the $m m o X$ sequences of methanotrophs belonging to the Beijerinckiaceae, based on all known published sequences plus several unpublished sequences from Methylocella isolates in our collection (Dunfield et al., 2010). The PCR protocol consisted of 35 cycles of denaturation at $94{ }^{\circ} \mathrm{C}$ for $1 \mathrm{~min}$, primer annealing at $55^{\circ} \mathrm{C}$ for $1 \mathrm{~min}$ and elongation at $72{ }^{\circ} \mathrm{C}$ for $1 \mathrm{~min}$, with a final extension step at $72{ }^{\circ} \mathrm{C}$ for $7 \mathrm{~min}$. PCR-amplified gene fragments were purified using the Wizard PCR Preps DNA purification system (Promega) and sequenced on an ABI Prism 377 DNA sequencer (PE Applied Biosystems). Phylogenetic analysis was carried out using the ARB program package (Ludwig et al., 2004). Detection of mmoX and mxaF mRNA transcripts in cells of strain $\mathrm{AR} 4^{\mathrm{T}}$ after growth on methane, methanol or both substrates together was performed as described for Methylocystis sp. H2s by Belova et al. (2011) with the modification that RT-PCR of $m m o X$ and $m x a F$ transcripts was performed using the primer pairs mmoXA/mmoXmc1 (see above) and 1003f/1561r (McDonald \& Murrell, 1997).

Small (1-3 mm), opaque, pale-cream, circular colonies with an entire edge and a smooth surface developed on agar medium MM2 after incubation for 1 month at $24{ }^{\circ} \mathrm{C}$. Liquid cultures displayed white turbidity. Flocks of biomass in liquid cultures were formed after 14-16 days of incubation. Cells of strains AR4 ${ }^{\mathrm{T}}$, SOP9 and LAY were Gram-negative, non-motile, straight or slightly curved thin rods, $0.4-0.65 \mu \mathrm{m}$ wide and $1.1-3.0 \mu \mathrm{m}$ long. They reproduced by irregular fission and occurred singly (Fig. 1a) or were arranged in rosettes and misshapen cell clusters (Fig. 1b). The formation of rosettes was most pronounced in old (two or more weeks) cultures. No resting cell forms were observed. Overall, this cell morphology was highly similar to that of the recently described facultative methylotroph Methylovirgula ligni (Vorob'ev et al., 2009) and was clearly
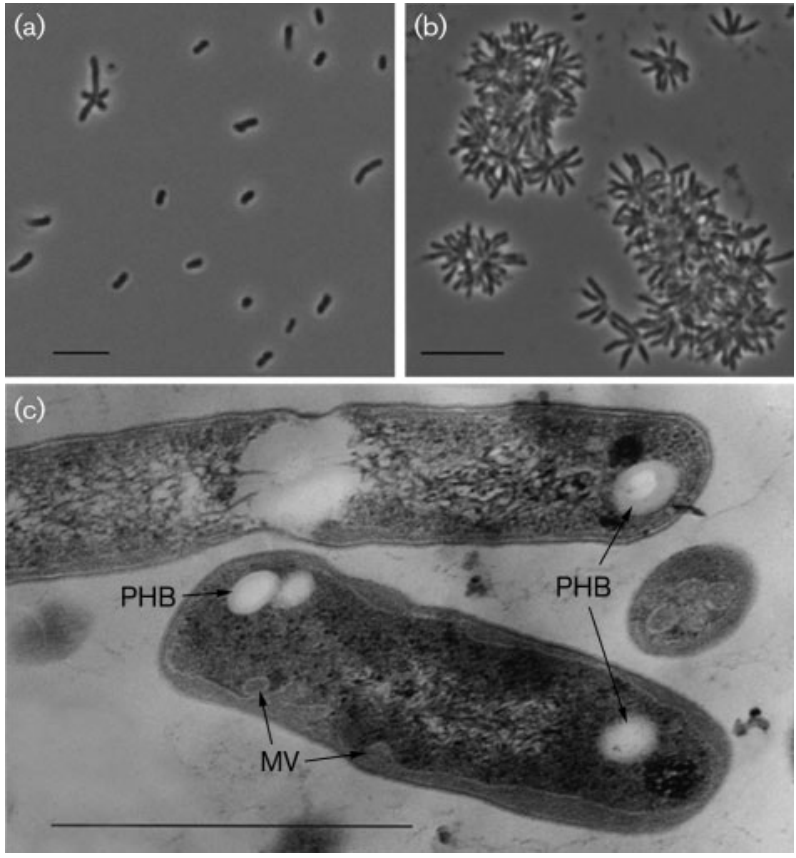

Fig. 1. $(a, b)$ Phase-contrast micrographs of cells of strain $A R 4^{\top}$ grown in liquid mineral medium MM2 with methanol for 5 (a) and 14 (b) days. (c) Electron micrograph of an ultrathin section of cells of strain SOP9. MV, Membrane vesicles; PHB, poly- $\beta$ hydroxybutyrate. Bars, $5 \mu \mathrm{m}(\mathrm{a}, \mathrm{b})$ and $1 \mu \mathrm{m}$ (c).

different from cell morphology in Methylocella species. Thin sections, however, revealed a cell ultrastructure similar to that observed in members of the genus Methylocella (Fig. 1c). The extensive ICM structures typical of pMMO-possessing proteobacterial methanotrophs were absent from cells of strains $\mathrm{AR} 4^{\mathrm{T}}$, SOP9 and LAY. Instead, the cells of these isolates contained a vesicular membrane system composed of spherical or ovoid-shaped membrane vesicles located on the periphery of the cytoplasm (Fig. 1c). Intracellular granules of poly- $\beta$-hydroxybutyrate were formed at each cell pole.

Strains AR4 ${ }^{\mathrm{T}}$, SOP9 and LAY were able to grow on methane as the sole carbon and energy source. However, the preferred growth substrate for these bacteria was methanol $\left(\mathrm{OD}_{600}^{\max }\right.$ $\left.0.65 ; \mu 0.015 \mathrm{~h}^{-1}\right)$ rather than methane $\left(\mathrm{OD}_{600}^{\max } 0.2 ; \mu\right.$ $\left.0.005 \mathrm{~h}^{-1}\right)$. It was utilized in a wide range of concentrations from 0.01 to $5 \%$, with an optimum between 0.1 and $1 \%$ $(\mathrm{v} / \mathrm{v})$. None of the other $\mathrm{C}_{1}$ compounds or multicarbon substrates tested supported growth of these strains. The preference for growth on methanol rather than methane is characteristic of pMMO-lacking methanotrophs, i.e. members of the genus Methylocella. Indeed, the presence of pMMO in strains $A R 4^{\mathrm{T}}$, SOP9 and LAY could not be confirmed by any of the commonly used approaches. Cells of these isolates did not contain ICM that are present in all pMMO-using methanotrophic proteobacteria. Our attempts to amplify a $p m o A$ gene fragment from DNA of 
strains $\mathrm{AR} 4^{\mathrm{T}}$, SOP9 and LAY using any of the following primer sets for this gene were unsuccessful: A189/A682 (Holmes et al., 1995), A189/Mb661r (Costello \& Lidstrom, 1999), A189/Mcap630r and A189/Forest675r (Kolb et al., 2003). In contrast, the colorimetric naphthalene oxidation test (Graham et al., 1992) for sMMO activity in cells of these isolates grown on both copper-free and copper-sufficient media was positive. We were able to amplify $m m o X$ gene fragments from DNA of these methanotrophs using the newly designed primer set. Comparative sequence analysis of $m m o X$ showed that the novel strains represent a lineage that is distinct from both type I and type II methanotrophs, but falls closer to Methylocella (83.3-85.7\% nucleotide sequence identity and 93.2-95.2\% deduced amino acid sequence identity) (Fig. 2). The identity between the deduced MmoX sequences of strains AR4 ${ }^{\mathrm{T}}$, SOP9 and LAY and those from the Methylosinus/Methylocystis group and type I methanotrophs was $86.6-88.3$ and $84.3-86.0 \%$, respectively.

Comparative sequence analysis of $m x a F$, the gene encoding the large subunit of methanol dehydrogenase, placed the MxaF sequences of our novel isolates in a cluster that was distinct from all previously described $\mathrm{MxaF}$ sequences of cultivated methylotrophs (Supplementary Fig. S1, available in IJSEM Online). The most closely related MxaF sequences (86.2-86.8\% identity) were those from the acidophilic methylotroph Methylovirgula ligni (Vorob'ev et al., 2009). The identity between the MxaF sequences of strains $\mathrm{AR} 4^{\mathrm{T}}$, SOP9 and LAY and MxaF sequences from other known alpha-, beta- and gammaproteobacterial methylotrophs was $67-81,63-66$ and $70-72 \%$, respectively. It is particularly remarkable that the $\mathrm{MxaF}$ sequences of the novel isolates were nearly identical $(98.8-100 \%)$ to the inferred peptide sequences of mxaF clones designated $\mathrm{MeOH} 1, \mathrm{MeOH} 2$ and M13.3 (GenBank accession numbers AY080938, AY080939 and AF200702) that were retrieved by means of a stable isotope probing technique from different acidic soils amended with ${ }^{13} \mathrm{C}$-methanol (Radajewski et al., 2000, 2002). Therefore, though these methanotrophs could not be detected by commonly used $m m o X$-targeted approaches, they were identified as metabolically active methylotroph populations in acidic soils by means of an mxaF-based approach.

The preference for growth on methanol raised a question concerning sMMO expression in the presence of methanol. To answer this question, we analysed extracts of total RNA from cells of strain $\mathrm{AR} 4^{\mathrm{T}}$ grown on methane or methanol or in the presence of both substrates for mmoX gene expression. mmoX mRNA transcripts were detected in cells grown on methane alone and on methane plus methanol, but they were not revealed in methanol-grown bacteria (Supplementary Fig. S2). As expected, mxaF mRNA transcripts were detected in all batches of cells examined in this experiment.

Since growth on methanol was more robust, we used extracts of methanol-grown cells to identify the routes of $\mathrm{C}_{1}$ assimilation in the novel methanotrophs. The novel strains possessed a pyrroloquinoline quinone-containing methanol dehydrogenase that required alkaline $\mathrm{pH}$ and ammonium ions for activity in vitro with phenazine methosulfate (PMS) as an artificial electron acceptor (Table 1). NAD-dependent formaldehyde and formate dehydrogenases were also detected. High activities of hydroxypyruvate reductase and serine-glyoxylate aminotransferase indicated that the novel isolates assimilate $\mathrm{C}_{1}$ compounds via the serine pathway. However, low activity of RubisCO was detected as well, suggesting that the RuBP pathway is also employed by these bacteria. Detection and partial sequence analysis of $r b c L$, the gene encoding form I RubisCO, provided genotypic evidence for the presence of

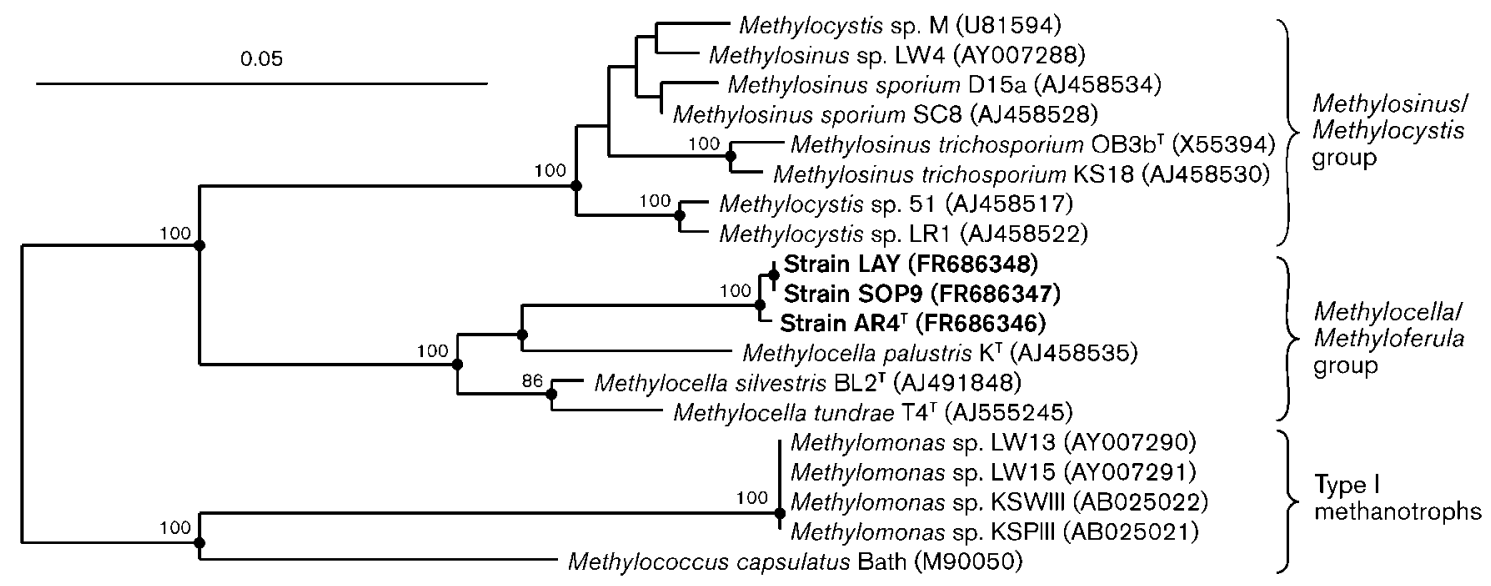

Fig. 2. Unrooted neighbour-joining tree reconstructed on the basis of 368 deduced amino acid sites of partial $m m o X$ gene sequences, showing the positions of strains AR4 ${ }^{\top}$, SOP9 and LAY relative to other sMMO-possessing type I and type II methanotrophs. Bootstrap values (1000 data resamplings) $>60 \%$ are shown. Filled circles indicate that the corresponding nodes were also recovered in maximum-likelihood and maximum-parsimony trees. Bar, 0.05 substitutions per nucleotide position. 
Table 1. Enzyme activities in cell extracts of strain $A R 4^{\top}$ grown on methanol

\begin{tabular}{|c|c|c|}
\hline Enzyme & Cofactor(s) & Activity $\left[\mathrm{nmol} \min ^{-1}\left(\mathrm{mg}\right.\right.$ protein $\left.\left.{ }^{-1}\right)\right]$ \\
\hline Methanol dehydrogenase & $\mathrm{PMS}^{*}$ & 1690 \\
\hline Formaldehyde dehydrogenase & $\mathrm{NAD}^{+}$ & 70 \\
\hline Formate dehydrogenase & $\mathrm{NAD}^{+}$ & 120 \\
\hline Hydroxypyruvate reductase & $\mathrm{NADH}, \mathrm{NADPH}_{2}$ & 190,4500 \\
\hline Serine-glyoxylate aminotransferase & $\mathrm{NADH}, \mathrm{NADPH}_{2}$ & 146,115 \\
\hline Malyl-CoA synthetase/CoA lyase & ATP, CoA & 5 \\
\hline RubisCO & - & 24 \\
\hline
\end{tabular}

*PMS, Phenazine methosulfate.

an autotrophic metabolism in the novel methanotrophs. The highest nucleotide sequence identity to the $r b c L$ gene fragments from these isolates was noted for Methylocella silvestris $\mathrm{BL} 2^{\mathrm{T}}$ (88\% identity) and Beijerinckia mobilis $(88 \%)$. Of these two organisms, RubisCO activities have been detected only in Beijerinckia mobilis (Dedysh et al., 2005b). Since the genome sequence of Methylocella silvestris $\mathrm{BL} 2^{\mathrm{T}}$ confirms the presence of genes encoding RubisCO (Chen et al., 2010), we repeated our analysis of Methylocella silvestris $\mathrm{BL} 2^{\mathrm{T}}$ grown on methanol, but still no RubisCO activity was detected under these growth conditions.

Strains $\mathrm{AR} 4^{\mathrm{T}}$, SOP9 and LAY utilized ammonium salts, nitrates, urea and yeast extract as nitrogen sources. They were also capable of slow growth in liquid nitrogen-free medium MM2 under microaerobic conditions (1.0-2.0\% $\mathrm{O}_{2}$ in the flask headspace). The sequences of nifH gene fragments from these methanotrophs displayed highest similarity (97-98\%) to the corresponding gene fragments from acidophilic methanotrophs of the genus Methylocapsa and members of the genus Beijerinckia.

The isolates were moderately acidophilic and grew in the $\mathrm{pH}$ range 3.5-7.2, with optimum growth at $\mathrm{pH} 4.8-5.2$ (Supplementary Fig. S3a). The temperature range for growth was $4-33{ }^{\circ} \mathrm{C}$, with optimum growth at $20-23{ }^{\circ} \mathrm{C}$ (Supplementary Fig. S3b). No growth occurred at $37{ }^{\circ} \mathrm{C}$. Growth of strains $\mathrm{AR} 4^{\mathrm{T}}$, SOP9 and LAY was inhibited in the presence of $\mathrm{NaCl}$ in the medium at concentrations above $0.7 \%(\mathrm{w} / \mathrm{v})$.

Table 2. PLFA compositions of strains $A R 4^{\top}$, SOP9 and LAY and phylogenetically related methanotrophs and methylotrophs of the family Beijerinckiaceae

Major PLFAs are shown in bold. Values are percentages of total fatty acids. PLFAs that made up $<0.1 \%$ of total in all organisms are not included. Data for reference taxa were taken from Dedysh et al. (2000, 2004a), Dunfield et al. (2003, 2010) and Vorob'ev et al. (2009).

\begin{tabular}{|c|c|c|c|c|c|c|}
\hline Fatty acid & $\mathrm{AR} 4^{\mathrm{T}}$ & SOP9 & LAY & Methylocella & Methylocapsa & Methylovirgula ligni \\
\hline $13: 0$ & 0 & 0 & 0.6 & 0 & $0-0.8$ & 0 \\
\hline $14: 0$ & 0.2 & 0.3 & 0.2 & $0-4.1$ & 0 & 0 \\
\hline iso- $15: 0$ & 0.7 & 0.9 & 1.0 & $0.2-1.2$ & $0.1-0.3$ & 0 \\
\hline $16: 0$ & 4.9 & 5.1 & 5.8 & $3.0-7.7$ & $5.9-7.3$ & $1.8-2.0$ \\
\hline 10-Methyl 16:0 & 0.4 & 0.3 & 0 & 0 & 0 & $0-0.4$ \\
\hline $16: 1 \omega 7 c$ & 2.6 & 2.6 & 3.6 & $6.8-11.3$ & $4.7-6.3$ & $0.3-0.4$ \\
\hline $16: 1 \omega 7 t$ & 0 & 0 & 0 & $0-5.8$ & 0 & 0 \\
\hline $16: 1 \omega 11 c$ & 0.8 & 0.8 & 0.3 & 0 & 0 & 0 \\
\hline iso- $17: 0$ & 0.7 & 0.9 & 1.0 & $0-2.5$ & $0.6-0.9$ & $0-0.2$ \\
\hline $17: 0$ cyclo & 0 & 0.2 & 0.2 & $0-6.5$ & 0 & $0-0.2$ \\
\hline $17: 1 \omega 7 c$ & 0.3 & 0.3 & 0 & 0 & $0-1.0$ & 0.2 \\
\hline iso- $18: 0$ & 0 & 0 & 0 & $0-0.5$ & 0 & 0 \\
\hline $18: 0$ & 0.6 & 0.6 & 0.9 & $0.4-1.2$ & $0.8-7.6$ & $0.8-0.9$ \\
\hline $18: 1 \omega 9 c$ & 0.4 & 0.3 & 0 & 0 & $0-0.4$ & $0-0.4$ \\
\hline $18: 1 \omega 7 c$ & 85.7 & 83.2 & 82.3 & $59.2-82.2$ & $78.3-81.5$ & 87.1-92.8 \\
\hline $19: 0$ cyclo $\omega 8 c$ & 1.3 & 3.8 & 2.5 & 0-13.6 & $0-2.5$ & 0 \\
\hline 19:0 cyclo & 0 & 0 & 0 & 0 & 0 & $1.4-2.6$ \\
\hline iso-19:0 & 0 & 0 & 0.4 & 0 & 0 & 0 \\
\hline $19: 0$ & 0.9 & 0.7 & 0.8 & $0-0.6$ & 0 & 0 \\
\hline 10-Methyl 19:0 & 0.2 & 0.2 & 0.3 & 0 & 0 & 0 \\
\hline
\end{tabular}




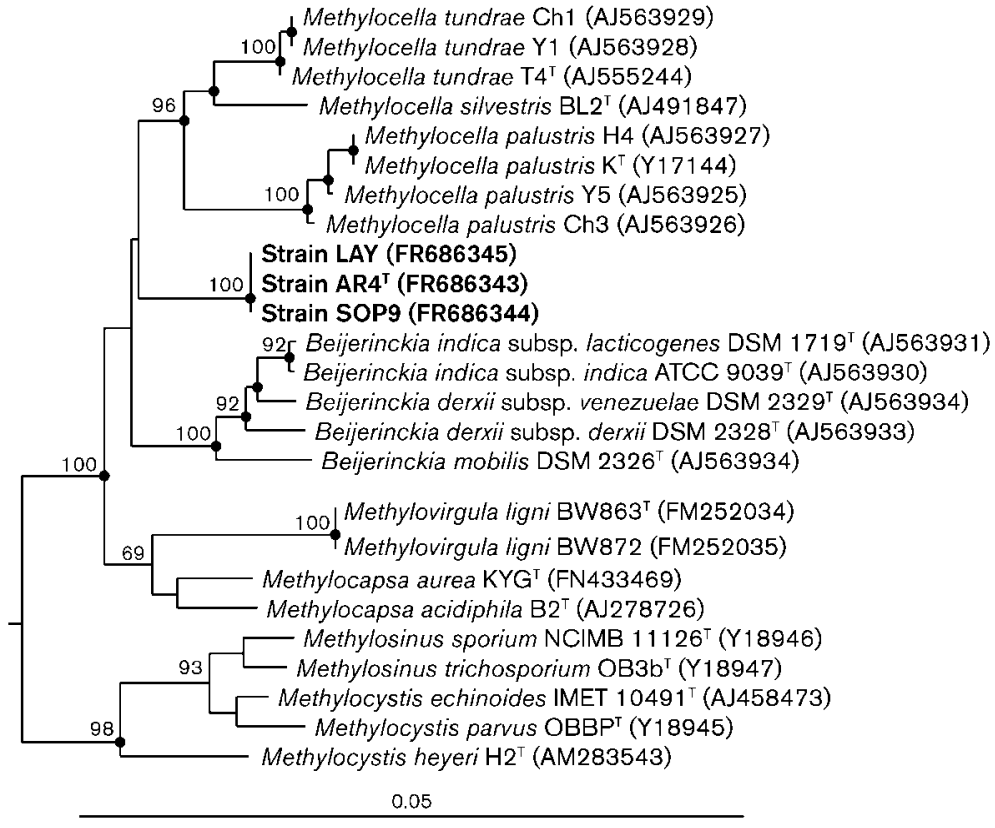

Fig. 3. $16 \mathrm{~S}$ rRNA gene sequence-based neighbour-joining tree showing the phylogenetic positions of strains $A R 4^{\top}$, SOP9 and LAY in relation to other members of the family Beijerinckiaceae and some other methanotrophic representatives of the Alphaproteobacteria. Bootstrap values (percentages of 1000 data resamplings) $>50 \%$ are shown. Filled circles indicate that the corresponding nodes were also recovered in maximum-likelihood and maximum-parsimony trees. Sequences from the type I methanotrophs Methylomicrobium album ACM $3314^{\top}$ (GenBank accession no. X72777), Methylobacter luteus NCIMB 11914 ${ }^{\top}$ (AF304195), Methylomonas methanica $\mathrm{S}^{\top}$ (AF304196) and Methylococcus capsulatus Texas (AJ563935) were used as an outgroup. Bar, 0.05 substitutions per nucleotide position.
Phospholipid fatty acid (PLFA) profiles of the novel methanotrophic isolates were highly similar to those described for methano- and methylotrophic representatives of the family Beijerinckiaceae, i.e. the genera Methylocella, Methylocapsa and Methylovirgula (Table 2). The major component of the PLFA profiles of the novel isolates was 11-cis-octadecenoic acid $(18: 1 \omega 7 c)$, which comprised $83.2-85.7 \%$ of the total fatty acids. Besides $18: 1 \omega 7 c$, strains $\mathrm{AR} 4^{\mathrm{T}}$, SOP9 and LAY contained significant amounts $(4.9-5.1 \%)$ of palmitic acid $(16: 0)$.

A phylogenetic tree constructed on the basis of $16 \mathrm{~S}$ rRNA gene sequences (Fig. 3 ) indicated that strains $\mathrm{AR}^{\mathrm{T}}$, SOP9 and LAY belong to the family Beijerinckiaceae of the class Alphaproteobacteria. The closest phylogenetic neighbours of these isolates are sMMO-possessing facultative methanotrophs of the genus Methylocella (96.4-97.0\% sequence similarity), heterotrophs of the genus Beijerinckia (96.5$97.0 \%)$, pMMO-possessing methanotrophs of the genus Methylocapsa (96.1-97.0\%) and facultative methylotrophs of the genus Methylovirgula (96.1-96.3\%). Members of the Methylosinus/Methylocystis group displayed only 93.6$94.6 \% 16 \mathrm{~S}$ rRNA gene sequence similarity to strains $\mathrm{AR}^{\mathrm{T}}$, SOP9 and LAY. The G $+\mathrm{C}$ content of the DNA in strains $\mathrm{AR} 4^{\mathrm{T}}$, SOP9 and LAY was $55.6-57.5 \mathrm{~mol} \%$.

In summary, our novel sMMO-possessing isolates from Sphagnum peat bogs and acidic soil possessed a number of characteristics that clearly distinguished them from other currently known methanotrophic members of the family Beijerinckiaceae (Table 3). Cell morphology, the absence of ICM and pMMO and the preference for growth on methanol made these strains different from members of the genus Methylocapsa. Formation of rosettes, the ability to grow at below $\mathrm{pH} 4$, the inability to utilize multicarbon compounds and the presence of RubisCO activity distinguished strains AR4 ${ }^{\mathrm{T}}$, SOP9 and LAY from Methylocella species. Therefore, we propose a novel genus and species, Methyloferula stellata gen. nov., sp. nov., to accommodate strains $\mathrm{AR}^{\mathrm{T}}$, SOP9 and LAY.

\section{Description of Methyloferula gen. nov.}

Methyloferula [Me.thy'lo.fe'ru.la. N.L. n. methylum the methyl group (from French methyle, back-formation from French methylune, coined from Gr. n. methu wine and Gr. n. hulê wood); N.L. pref. methyl- pertaining to the methyl radical; L. fem. n. ferula a rod; N.L. fem. n. Methyloferula methyl-using rod].

Gram-negative, aerobic, colourless, non-motile rods that occur singly or are arranged in rosettes and misshapen cell clusters. Reproduce by irregular fission. Colonies are small, circular and smooth. The colony colour varies from white to cream. Produce poly- $\beta$-hydroxybutyrate. Mesophilic and moderately acidophilic. Prefer dilute media of low salt content. Obligate utilizers of methane and methanol; the latter is the preferred growth substrate. Possess only a soluble MMO. Capable of atmospheric nitrogen fixation. The major fatty acid is $18: 1 \omega 7 c$. The major quinone is $\mathrm{Q}-10$. The G $+\mathrm{C}$ content of the DNA is $55.6-57.5 \mathrm{~mol} \%$. Member of the class Alphaproteobacteria, family Beijerinckiaceae. The type and only species is Methyloferula stellata. Known habitats are acidic peatlands and soils.

\section{Description of Methyloferula stellata sp. nov.}

Methyloferula stellata (stel.la'ta. L. fem. adj. stellata starry).

Description as for the genus plus the following traits. Cells are $0.4-0.65 \mu \mathrm{m}$ wide and $1.1-3.0 \mu \mathrm{m}$ long. Carbon 
Table 3. Major characteristics that distinguish the novel strains (Methyloferula gen. nov.) from other methanotrophs of the family Beijerinckiaceae

Data for Methylocella were taken from Dedysh et al. (2000, 2004a, 2005a) and Dunfield et al. (2003) and data for Methylocapsa were taken from Dedysh et al. (2002) and Dunfield et al. (2010).

\begin{tabular}{|c|c|c|c|}
\hline Characteristic & Methyloferula gen. nov. & Methylocella & Methylocapsa \\
\hline Cell morphology & Straight or curved rods & Bipolar straight or curved rods & Curved coccoids \\
\hline Cell size $(\mu \mathrm{m})$ & $0.4-0.65 \times 1.1-3.0$ & $0.6-1.0 \times 1.0-2.5$ & $0.7-1.2 \times 0.8-3.1$ \\
\hline Rosette formation & + & - & - \\
\hline Type of methanotrophy & Obligate & Facultative & Obligate or facultative \\
\hline \multicolumn{4}{|l|}{ Possession of: } \\
\hline pMMO & - & - & + \\
\hline sMMO & + & + & - \\
\hline Preferable growth substrate(s) & Methanol & Methanol, acetate & Methane \\
\hline Multicarbon compounds utilized & None & $\begin{array}{c}\text { Acetate, pyruvate, succinate, malate, } \\
\text { ethanol }\end{array}$ & None or acetate ${ }^{\star}$ \\
\hline RubisCO activity & + & - & - \\
\hline \multicolumn{4}{|l|}{ Growth at/in: } \\
\hline $\mathrm{pH} 3.5$ & + & - & - \\
\hline $0.5 \% \mathrm{NaCl}$ & + & - & - \\
\hline DNA G $+C$ content $(\mathrm{mol} \%)$ & $55.6-57.5$ & $60-63.3$ & 57.3 \\
\hline
\end{tabular}

${ }^{*}$ Methylocapsa acidiphila does not utilize multicarbon compounds, while Methylocapsa aurea utilizes acetate.

sources include methane and methanol. Grows optimally at methanol concentrations of $0.5-1 \%$. Nitrogen sources $(0.05 \%, w / v)$ include ammonia, nitrate, urea and yeast extract. Capable of growth at $\mathrm{pH} 3.5-7.2$ (optimum $\mathrm{pH} 4.8-5.2$ ) and at $4-33{ }^{\circ} \mathrm{C}$ (optimum $20-23{ }^{\circ} \mathrm{C}$ ). $\mathrm{NaCl}$ inhibits growth at concentrations above $0.7 \%(\mathrm{w} / \mathrm{v})$.

The type strain is strain $\mathrm{AR}^{\mathrm{T}}$ (=DSM $22108^{\mathrm{T}}=\mathrm{LMG}$ $25277^{\mathrm{T}}=$ VKM B-2543 ${ }^{\mathrm{T}}$ ), which was isolated from the oligo-mesotrophic fen Torfjanoye, Archangelsk region, European North Russia $\left(65^{\circ} 01^{\prime} \mathrm{N} 35^{\circ} 44^{\prime} \mathrm{E}\right)$.

\section{Acknowledgements}

This research was supported by the Program 'Molecular and Cell Biology' of the Russian Academy of Sciences, by the RosNauka project no. 02.740.11.0023 and by an Alberta Innovates-Technology Futures New Faculty Award. The authors want to thank N. E. Suzina for electron microscopy and E. N. Detkova for DNA G + C content analysis.

\section{References}

Auman, A. J., Stolyar, S., Costello, A. M. \& Lidstrom, M. E. (2000). Molecular characterization of methanotrophic isolates from freshwater lake sediment. Appl Environ Microbiol 66, 5259-5266.

Belova, S. E., Baani, M., Suzina, N. E., Bodelier, P. L. E., Liesack, W. \& Dedysh, S. N. (2011). Acetate utilization as a survival strategy of peatinhabiting Methylocystis spp. Environ Microbiol Reports 3, 36-46.

Chen, Y., Crombie, A., Rahman, M. T., Dedysh, S. N., Liesack, W., Stott, M. B., Alam, M., Theisen, A. R., Murrell, J. C. \& Dunfield, P. F. (2010). Complete genome sequence of the aerobic facultative methanotroph Methylocella silvestris BL2. J Bacteriol 192, 3840-3841.
Collins, M. D. (1985). Analysis of isoprenoid quinones. Methods Microbiol 18, 329-366.

Costello, A. M. \& Lidstrom, M. E. (1999). Molecular characterization of functional and phylogenetic genes from natural populations of methanotrophs in lake sediments. Appl Environ Microbiol 65, 50665074.

Dedysh, S. N. \& Dunfield, P. F. (2010). Facultative methane oxidizers. In Handbook of Hydrocarbon and Lipid Microbiology, pp. 1967-1976. Edited by K. N. Timmis. Berlin: Springer.

Dedysh, S. N., Liesack, W., Khmelenina, V. N., Suzina, N. E., Trotsenko, Y. A., Semrau, J. D., Bares, A. M., Panikov, N. S. \& Tiedje, J. M. (2000). Methylocella palustris gen. nov., sp. nov., a new methaneoxidizing acidophilic bacterium from peat bogs, representing a novel subtype of serine-pathway methanotrophs. Int J Syst Evol Microbiol 50, 955-969.

Dedysh, S. N., Khmelenina, V. N., Suzina, N. E., Trotsenko, Y. A., Semrau, J. D., Liesack, W. \& Tiedje, J. M. (2002). Methylocapsa acidiphila gen. nov., sp. nov., a novel methane-oxidizing and dinitrogen-fixing acidophilic bacterium from Sphagnum bog. Int $J$ Syst Evol Microbiol 52, 251-261.

Dedysh, S. N., Berestovskaya, Y. Y., Vasylieva, L. V., Belova, S. E., Khmelenina, V. N., Suzina, N. E., Trotsenko, Y. A., Liesack, W. \& Zavarzin, G. A. (2004a). Methylocella tundrae sp. nov., a novel methanotrophic bacterium from acidic tundra peatlands. Int J Syst Evol Microbiol 54, 151-156.

Dedysh, S. N., Ricke, P. \& Liesack, W. (2004b). NifH and NifD phylogenies: an evolutionary basis for understanding nitrogen fixation capabilities of methanotrophic bacteria. Microbiology 150, 1301-1313.

Dedysh, S. N., Knief, C. \& Dunfield, P. F. (2005a). Methylocella species are facultatively methanotrophic. J Bacteriol 187, 4665-4670.

Dedysh, S. N., Smirnova, K. V., Khmelenina, V. N., Suzina, N. E., Liesack, W. \& Trotsenko, Y. A. (2005b). Methylotrophic autotrophy in Beijerinckia mobilis. J Bacteriol 187, 3884-3888. 
Dunfield, P. F., Khmelenina, V. N., Suzina, N. E., Trotsenko, Y. A. \& Dedysh, S. N. (2003). Methylocella silvestris sp. nov., a novel methanotroph isolated from an acidic forest cambisol. Int J Syst Evol Microbiol 53, 1231-1239.

Dunfield, P. F., Belova, S. E., Vorob'ev, A. V., Cornish, S. L. \& Dedysh, S. N. (2010). Methylocapsa aurea sp. nov., a facultative methanotroph possessing a particulate methane monooxygenase, and emended description of the genus Methylocapsa. Int J Syst Evol Microbiol 60, 2659-2664.

Graham, D. W., Korich, D. G., LeBlanc, R. P., Sinclair, N. A. \& Arnold, R. G. (1992). Applications of a colorimetric plate assay for soluble methane monooxygenase activity. Appl Environ Microbiol 58, 2231-2236.

Hanson, R. S. \& Hanson, T. E. (1996). Methanotrophic bacteria. Microbiol Rev 60, 439-471.

Holmes, A. J., Costello, A., Lidstrom, M. E. \& Murrell, J. C. (1995). Evidence that particulate methane monooxygenase and ammonia monooxygenase may be evolutionarily related. FEMS Microbiol Lett 132, 203-208.

Kämpfer, P. \& Kroppenstedt, R. M. (1996). Numerical analysis of fatty acid patterns of the coryneform bacteria and related taxa. Can J Microbiol 42, 989-1005.

Kolb, S., Knief, C., Stubner, S. \& Conrad, R. (2003). Quantitative detection of methanotrophs in soil by novel pmoA-targeted real-time PCR assays. Appl Environ Microbiol 69, 2423-2429.

Ludwig, W., Strunk, O., Westram, R., Richter, L., Meier, H., Yadhukumar, Buchner, A., Lai, T., Steppi, S. \& other authors (2004). ARB: a software environment for sequence data. Nucleic Acids Res 32, 1363-1371.

McDonald, I. R. \& Murrell, J. C. (1997). The methanol dehydrogenase structural gene $m x a F$ and its use as a functional gene probe for methanotrophs and methylotrophs. Appl Environ Microbiol 63, 32183224

McDonald, I. R., Kenna, E. M. \& Murrell, J. C. (1995). Detection of methanotrophic bacteria in environmental samples with the PCR. Appl Environ Microbiol 61, 116-121.

Miguez, C. B., Bourque, D., Sealy, J. A., Greer, C. W. \& Groleau, D. (1997). Detection and isolation of methanotrophic bacteria possessing soluble methane monooxygenase (sMMO) genes using the polymerase chain reaction (PCR). Microb Ecol 33, 21-31.
Op den Camp, H. J. M., Islam, T., Stott, M. B., Harhangi, H. R., Hynes, A., Schouten, S., Jetten, M. S. M., Birkeland, N.-K., Pol, A. \& Dunfield, P. F. (2009). Environmental, genomic and taxonomic perspectives on methanotrophic Verrucomicrobia. Environ Microbiol Reports 1, 293306.

Owen, R. J., Hill, L. R. \& Lapage, S. P. (1969). Determination of DNA base compositions from melting profiles in dilute buffers. Biopolymers 7, 503-516.

Radajewski, S., Ineson, P., Parekh, N. R. \& Murrell, J. C. (2000). Stable-isotope probing as a tool in microbial ecology. Nature 403, 646-649.

Radajewski, S., Webster, G., Reay, D. S., Morris, S. A., Ineson, P., Nedwell, D. B., Prosser, J. I. \& Murrell, J. C. (2002). Identification of active methylotroph populations in an acidic forest soil by stableisotope probing. Microbiology 148, 2331-2342.

Reynolds, E. S. (1963). The use of lead citrate at high $\mathrm{pH}$ as an electron-opaque stain in electron microscopy. J Cell Biol 17, 208-212.

Shigematsu, T., Hanada, S., Eguchi, M., Kamagata, Y., Kanagawa, T. \& Kurane, R. (1999). Soluble methane monooxygenase gene clusters from trichloroethylene-degrading Methylomonas sp. strains and detection of methanotrophs during in situ bioremediation. Appl Environ Microbiol 65, 5198-5206.

Spiridonova, E. M., Berg, I. A., Kolganova, T. V., Ivanovsky, R. N., Kuznetsov, B. B. \& Turova, T. P. (2004). An oligonucleotide primer system for amplification of the ribulose-1,5-bisphosphate carboxylase/oxygenase genes of bacteria of various taxonomic groups. Microbiology [English translation of Mikrobiologiia] 73, 316-325.

Theisen, A. R., Ali, M. H., Radajewski, S., Dumont, M. G., Dunfield, P. F., McDonald, I. R., Dedysh, S. N., Miguez, C. B. \& Murrell, J. C. (2005). Regulation of methane oxidation in the facultative methanotroph Methylocella silvestris BL2. Mol Microbiol 58, 682-692.

Vorob'ev, A. V., de Boer, W., Folman, L. B., Bodelier, P. L. E., Doronina, N. V., Suzina, N. E., Trotsenko, Y. A. \& Dedysh, S. N. (2009). Methylovirgula ligni gen. nov., sp. nov., an obligately acidophilic, facultatively methylotrophic bacterium with a highly divergent mxaF gene. Int J Syst Evol Microbiol 59, 2538-2545.

Weisburg, W. G., Barns, S. M., Pelletier, D. A. \& Lane, D. J. (1991). 16S ribosomal DNA amplification for phylogenetic study. J Bacteriol 173 697-703. 